\title{
RAINFALL VARIABILITY IN GUNUNG SEWU KARST AREA, JAVA ISLAND, INDONESIA
}

\author{
Ahmad Cahyadi ${ }^{1 *}$, Eko Haryono ${ }^{2}$, Tjahyo Nugroho Adji ${ }^{2}$, Margaretha Widyastuti ${ }^{2}$, Indra Agus \\ Riyanto $^{3}$, Dzakwan Taufiq Nur Muhammad ${ }^{1}$, and Naufal Fattah Tastian ${ }^{1}$ \\ ${ }^{1}$ Department of Environmental Geography, Universitas Gadjah Mada, \\ Sekip Utara Jalan Kaliurang, Bulaksumur, Yogyakarta, 55281 Indonesia \\ ${ }^{2}$ Karst Research Group, Universitas Gadjah Mada, \\ Sekip Utara, Jalan Kaliurang Bulaksumur, Yogyakarta. 55281 Indonesia \\ ${ }^{3}$ Lentera Geosains Yogyakarta, \\ Jl. Tongkol V, Minomartani, Ngaglik, Sleman, Yogyakarta Indonesia
}

Received: 21 October 2020, Revised: 5 April 2021, Accepted: 6 April 2021

\begin{abstract}
RAINFALL VARIABILITY IN GUNUNG SEWU KARST AREA, JAVA ISLAND, INDONESIA.Karst area is highly susceptible to changes to climate parameters. One of the parameters is rainfall variability. In addition to shaping the condition of water resources, rainfall in the Gunung Sewu karst area determines the nature of crop and livestock of the agriculture sectors-the local population's main economic activities, warranting the significance of the rainfall variability studies. Rainfall variability in karst areas also affects disaster conditions such as drought and floods. However, due to insufficient meteorological data in quality and quantity, there has been no rainfall variability studies conducted in this locality. The research intended to analyze rainfall variability in the Gunung Sewu karst area in 1979-2013 by utilizing rainfall predictions from satellite images that many scholars had tested in different locations and recognized as having good quality. In the analysis, mean monthly rainfall was calculated, and the trends of annual rainfall and average rainfall intensity, dry and rainy seasons, the number of rainy days, and the effect of ENSO (El Niño Southern Oscillation) on rainfall were analyzed. The research data were 35 years of daily rainfall records derived from the National Centers for Environmental Prediction (NCEP) Climate Forecast System Reanalysis (CFSR). The analysis results showed that the mean rainfall, number of rainy days, and rainfall intensity had an increasing trend. Also, El Niño quantitatively influenced the rain in the Gunung Kidul karst area.
\end{abstract}

Keywords: Rainfall variability, karst, ENSO, Gunung Sewu, NCEP, CFSR

VARIABILITAS CURAH HUJAN DI KAWASAN KARST GUNUNG SEWU, PULAU JAWA, INDONESLA. Kawasan karst merupakan kawasan yang sangat sensitif terbadap perubahan parameter iklim, salab satunya adalah pada variabilitas curah hujan. Variabilitas curah bujan menjadi sangat penting dikaji di kawasan karst Gunung Sewn karena selain sangat mempengarubi kondisi sumber daya air, curah bujan akan berpengarub terbadap sektor pertanian dan peternakan yang menjadi sektor ekonomi utama bagi masyarakat di kawasan karst Gunung Sewu. Variabilitas curah bujan di kawasan karst juga mempengarubi kondisi bencana seperti kekeeringan dan banjir. Namun demikian, analisis variabilitas di kawasan karst Gunung Sewu belum dilakukan karena ketersediaan data meteorologis yang kurang baik dari sisi kualitas ataupun kuantitas. Penelitian ini bertujuan untuk menganalisis variabilitas curah bujan di kawasan karst Gunung Sewu pada tabun 1979-2013 dengan memanfaatkan data prediksi dari citra satelit yang telah diuji oleh banyak peneliti di lokasi lain dan memiliki kualitas yang baik. Analisis variabilitas bujan yang dilakukan dalam penelitian ini meliputi perbitungan rerata bujan bulanan, analisis trend bujan tahunan, analisis bujan musim kemarau dan pengbujan, analisis jumlah hari bujan, analisis trend rata-rata intensitas bujan dan analisis pengarub ENSO (El Niño Southern Oscillation) terhadap curah bujan di kawasan karst Gunung Sewu. Data yang digunakan dalam penelitian ini berasal dari The National Centers for Environmental Prediction (NCEP) Climate Forecast System Reanalysis (CFSR). Data yang digunakan berupa data harian selama 35 tabun. Hasil analisis menunjukkan bahwa rerata curah bujan, jumlah hari bujan dan intensitas bujan memiliki trend kenaikan. Selain itu diketabui bawah bujan di kawasan karst Gunung Kidul secara kualitatif nampak sangat dipengarubi oleh peristiwa EL Niño.

Kata kunci: Variabilitas hujan, karst, ENSO, Gunung Sewn, NCEP, CFSR

${ }^{*}$ Corresponding author: ahmad.cahyadi@geo.ugm.ac.id 


\section{INTRODUCTION}

Karst landscapes are fragile and highly sensitive to environmental changes in which ecological restoration can be challenging to achieve quickly (Quine et al., 2017; Kang et al., 2020). The changes in question are those of hydrometeorological or climatic variables, which currently are prevalent issues. Dissolution as the dominant process in karst areas has led to a hydrologically dry surface because all water landing on this landscape is drained immediately into underground rivers (Cahyadi, 2014a). Here, water storage highly depends on the epikarst layer, i.e., the top layer of a karst landscape that consists of soil and the widening zone of fissures and conduits in carbonate rocks. In other words, soil thickness and the presence of loose rock grains strongly determine its capacity. However, resistance to rock disintegration has limited the formation of soils in high volume in a relatively short time of this landscape (Green et al., 2019). The epikarst layer requires a very long time to form.

Gunung Sewu is one of Indonesia's karst areas that reportedly experiences recurrent droughts (Cahyadi, Marfai, Rahmadana, \& Nucifera, 2012; Fatchurohman \& Cahyadi, 2013). Nevertheless, in the event of high rainfall, floods can still occur and affect the area. Gunung Sewu is highly susceptible to the variability of climatic parameters, especially rainfall. Apart from the strong influence on water resources, rainfall is also a crucial factor in crop and livestock agricultural practices, which are the main economic sectors in Gunung Sewu. Many of its inhabitants still rely on rain as a primary source of clean water throughout the rainy season, along with lakes and epikarst springs. Water availability is much dependent on rainfall. Even for merely a few months, the absence of rains can lower the water levels and dry out most of these lakes and epikarst springs. For these reasons, a study of rainfall variability is relatively important.

Gunung Sewu karst areais part of the Indonesian Maritime Continent that regulates many determinants of its rain variability, for example, the Asia-Australia monsoon, El Niño-Southern Oscillation (ENSO), eastwest circulations (Zonal/Walker circulation), north-south circulations (Meridional/Hadley Circulation) and some circulations that are heavily influenced by local factors (Hermawan, 2010; Aldrian, Gates, \& Widodo, 2007). In Indonesia, the complex climate conditions are attributed to many factors, to which every part of the country shows varying responses (Gutman, Csiszar, \& Romanov, 2000; Haylock \& McBride, 2001; Boer, 2003; Athoillah, Sibarani, \& Doloksaribu, 2017). Other studies have confirmed that southern Indonesia, including the Gunung Sewu Karst Area, is inclined to have higher rainfall variability than the northern side (Juaeni, 2006).

The climate of Java is significantly controlled by the Asian-Australian monsoon (Ramage, 1971; Aldrian, 2001). History has documented that ENSO contributes to shaping the rainfall on this island (Boer, Faqih, \& Ariani 2014). Further research stated that hills, mountains, and volcanoes in the southern and central parts of the island cause the southern side to be wetter than its northern counterpart (Qian, Robertson, \& Moron, 2010). In tropical studies, rainfall variability often takes precedence over other climatic parameters, given that it is the most influencing factor of plant productivity and water resources. The tropical condition may be linked to parameters other than rainfall that rarely experience similar large fluctuations (Naylor, Battisti, Vimont, Falcon, \& Burke, 2007). Furthermore, comprehensive knowledge of rainfall variability helps manage water resources, understand and reduce disaster risks, assist in infrastructure work schedule, and plan the agriculture, fishery, livestock, and tourism sectors (Stefanidis \& Stathis, 2018).

Rainfall variability analysis in the Gunung Sewu karstareais vital, butlong-term daily rainfall data required for the study remain insufficiently available. In total, the Gunung Kidul Regency has 13 rain gauge stations, three of which are in Gunung Sewu and since 1979 have long timeseries of records with low quality as too many 
data are missing: $42 \%$ of data is missing at Panggang, $46 \%$ at Tepus, and 38\% at Rongkop. However, their daily rainfall availability (ratio of filled to missing) shows that the data quality is improving. At this state, rainfall analysis instead should use satellite data with relatively complete long-term records. Besides, many studies have relied on these global data, which also have easy accessibility and high accuracy (Christanto, Setiawan, Nurkholis, Sartohadi, \& Hadi, 2020).

This research was intended to analyze the rainfall variability in the Gunung Sewu karst area from 1979 until 2013. A local-scale analysis is vital in that rainfall also varies depending on local factors (Hermawan, 2010; Hamada, Yamanaka, Matsumoto, Fukao, Winarso, \& Sribimawati, 2002). This research is expected to contribute to climate variability at the study site to formulate the most appropriate plans to meet water needs in karst areas in the future. Furthermore, it can be used to understand rainfall characteristics, especially in temporal studies, as reference material for mitigating meteorological disasters.

\section{MATERIAL AND METHOD}

This report's climatological data are rainfall data obtained from the Global Weather Data for the SWAT (Soil and Water Assessment Tool) program. The data are accessible at https:// globalweather.tamu.edu. Analyses were then conducted to produce the desired data. Daily rainfall data were generated from the National Centers for Environmental Prediction (NCEP) Climate Forecast System Reanalysis (CFSR), global coverage and adequately high resolution. These data cover the years from 1979 to mid2013 (data length $=35$ years).
The spatial resolution of the CFSR data is 38 $\mathrm{km}$ or 0.3125 degrees. Therefore, Fuka, Walter, Macalister, Degaetano, Steenhuis, and Easton, 2014) stated that this data is very suitable for studies on an area of about 40 square $\mathrm{km}^{2}$. This study only represents the Gunung Sewu karst area in the Gunung Kidul Regency, Yogyakarta. Dile and Srinivasan (2014) stated that the CFSR data's accuracy compared to the rain recording data on the ground station is high. The difference between the CFSR data and the ground station is between $5.8 \%$ and $28.57 \%$, with an average of $16.02 \%$. However, the studies of data utilization from Fuka, Macalister, Degaetano, Steenhuis, \& Easton (2014) in the USA and Ethiopia, Dile and Srinivasan (2014) in the Blue Nile River Basin, Ethiopia and Christanto, Setiawan, Setiawan, Sartohadi, \& Hadi (2020) in Serayu Watershed, Indonesia, showed an excellent performance even as an input to further hydrological models such as runoff modelling or water balance in a watershed.

Here, the rainfall variability was determined by calculating mean monthly rainfall and analyzing trends of annual rainfall and mean rainfall intensity, dry and rainy seasons, the number of rainy days, and the effect of ENSO on rains in the Gunung Sewu karst area. Rainfall trends, intensity, and the number of rainy days were analyzed using linear regression. In contrast, the effect of ENSO on rainfall variability was analyzed descriptively from the rain characteristics during the El Niño and La Niña months or years. Data on these El Niño and La Niña events were obtained from the National Oceanic and Atmospheric Administration website, US Department of Commerce, i.e., https://noaa. gov. In this

Table 1. El Niño and La Niña classification based on ONI values

\begin{tabular}{clcl}
\hline ONI Value Range & Classification & ONI Value Range & Classification \\
\hline $0.5-1.0$ & Week El Niño & $-1.0-<-0.5$ & Week La Niña \\
$>1.0-1.5$ & Moderate El Niño & $-1.5-<-1.0$ & Moderate La Niña \\
$>1.5-2.0$ & Strong El Niño & $-2.0-<-1.5$ & Strong La Niña \\
$>2.0$ & Very Strong El Niño & $<-2.0$ & Very Strong La Niña \\
\hline
\end{tabular}


research, El Niño and La Niña occurrences were classified according to the Oceanic Niño Index (ONI) values, i.e., NOAA's main parameter used to determine each. ONI values were measured from sea surface temperature in the Niño 3.4 region, where $\mathrm{ONI}>0.5$ marks an $\mathrm{El}$ Niño occurrence, whereas ONI $=-0.5$ indicates La Niña. Table 1 shows the El Niño-La Niña classification details used in this research.

This research's data coverage represents the western part of the Gunung Sewu karst area, which includes Gunung Kidul Regency. Nevertheless, the study is expected to provide various related parties with a representative overview of the area as an input to their decision-making processes. This data coverage is considered adequate, given that groundwater resource and disaster management in Indonesia are currently part of provincial and local government's responsibility, respectively. Discussion on water resources in the western part of the karst areais believed to give more focused details and thoughts as a contribution to Gunung Kidul Regency's governments and the Yogyakarta Province.

\section{III.RESULT AND DISCUSSION}

The analysis of rainfall data from 1979 to 2013 revealed that the Gunung Sewu karst area's monthly rainfall showed a monsoonal pattern. It shows the horse saddle-like shape in Figure 1. High rain lasted from January to March and November to December, whereas low rainfall occurred from May-September. April and October were transitional months between these two seasons. The highest rainfall, $258 \mathrm{~mm} / \mathrm{month}$, was found in February, and the lowest, $15 \mathrm{~mm} / \mathrm{month}$, occurred in August. These characteristics support the argument that the monsoon winds and the Intertropical Convergence Zone (ITCZ) control the wet period in November-March (Asnani, 1993). It is consistent with Aldrian (2001), who categorized the study area into the climate region A-also known as the Australian Monsoon Region-where monsoon winds strongly affect the rainfall pattern. Another corroborating opinion is that Java Island, where the Gunung Sewu karst area is located, is the center of the Australian-Asian Monsoon Region (Ramage, 1968). Because of this, the monsoon wind tends to exert a substantial effect on the climate of the study area.

The annual rainfall in the Gunung Sewu karst area was, on average, $1,831 \mathrm{~mm} /$ year. The highest rainfall, $3,885 \mathrm{~mm} /$ year, occurred in 2010, while the lowest was $909 \mathrm{~mm} / \mathrm{year}$, which appeared in 1982. Figure 2 shows an

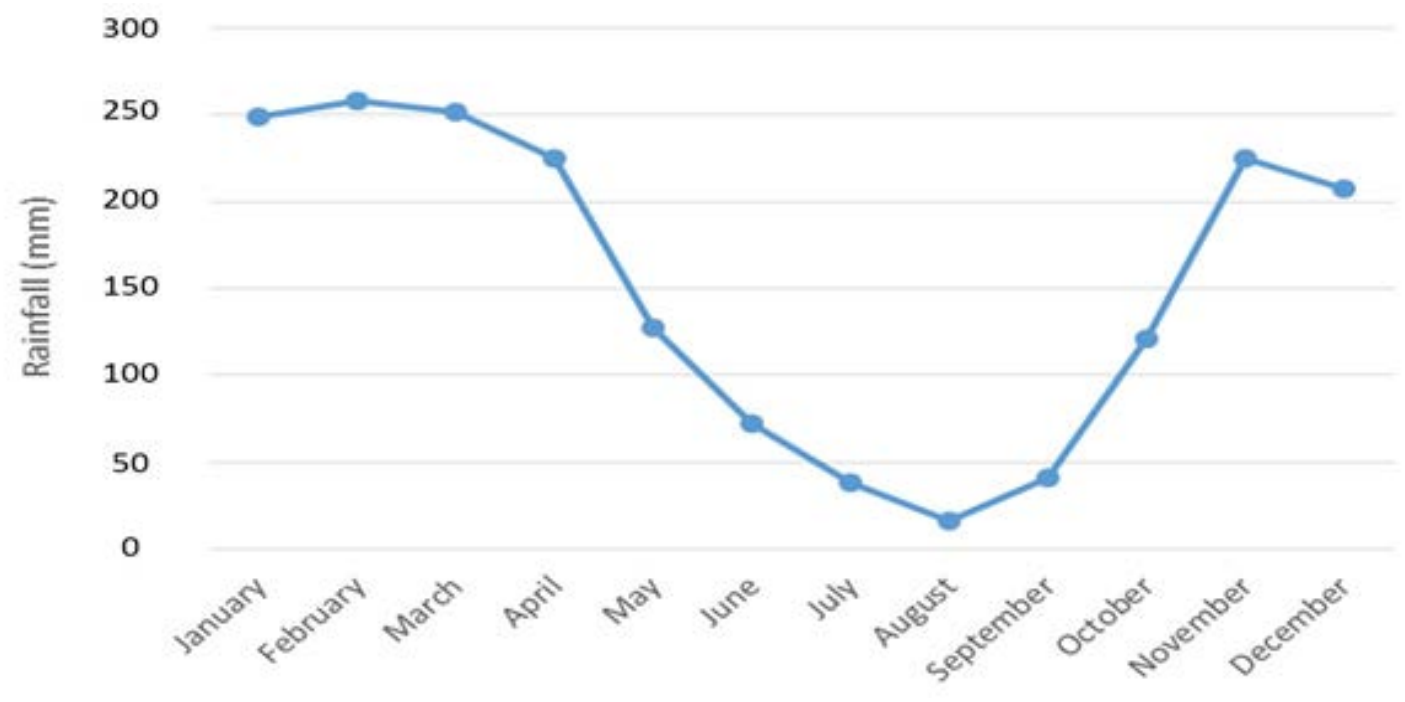

Figure 1. Mean monthly rainfall in the Gunung Sewu karst area 


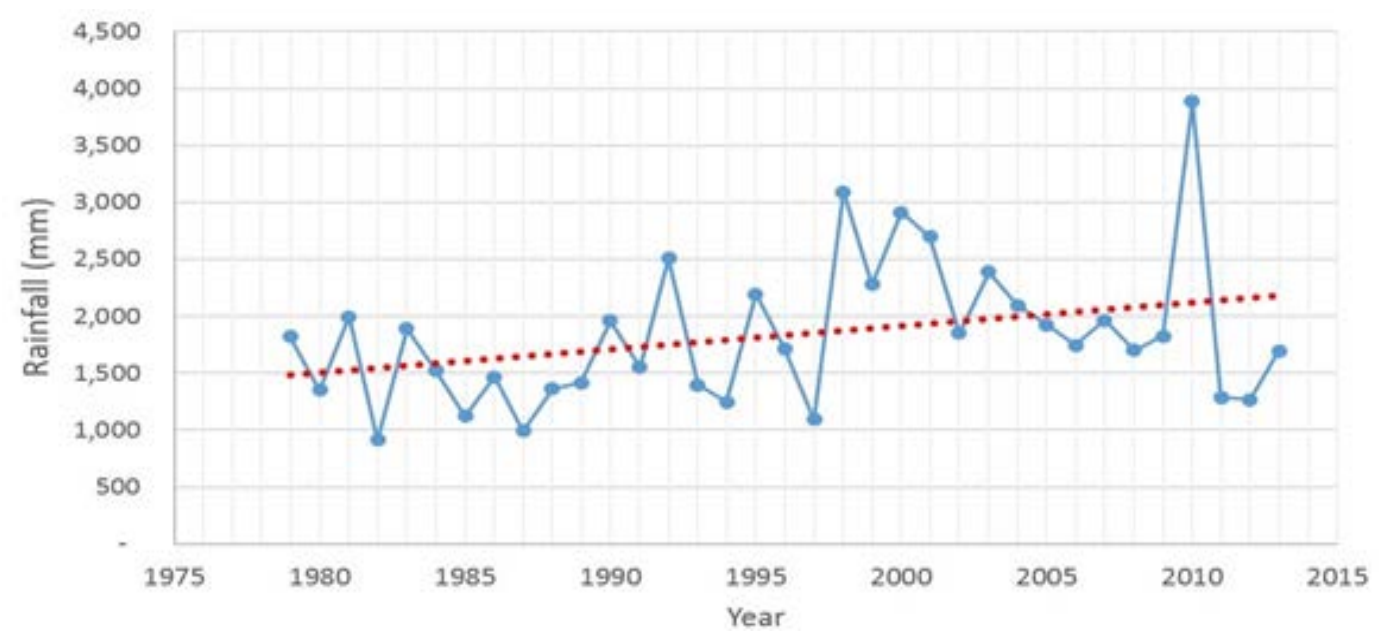

Figure 2. The trend of the annual rainfall in the Gunung Sewu karst area

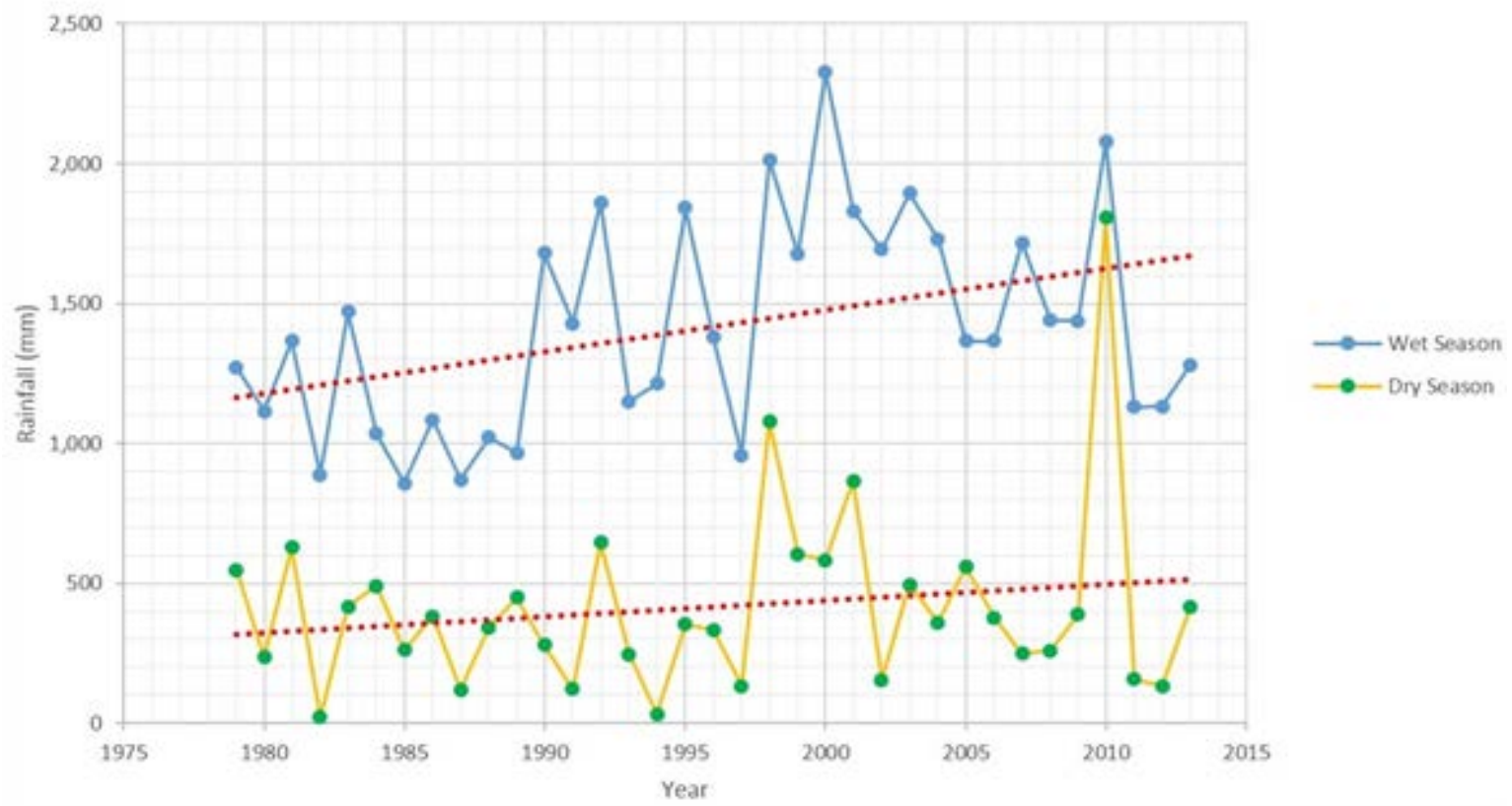

Figure 3. The trend of rainfall in rainy and dry seasons in the Gunung Sewu karst area

increasing trend of annual rainfall by $\pm 650 \mathrm{~mm}$ in 35 years. Prior scholars have also reported similar trends in neighbouring regions, Sleman Regency, Yogyakarta City, and Bantul Regency (Dipayana, Cahyadi, Mutaqin, \& Nurjani, 2012a; Dipayana, Nurjani, \& Adji, 2012b), and Magelang Regency that is located relatively close to the study site (Suprayogi et al., 2014). However, Figure 3 shows that rainfall in the rainy and dry seasons increased at different magnitudes (the determination of the dry and rainy seasons follows (Brunsch, Stoffel,
Ikhwan, Oberle, \& Nestmann, 2011), in which the rainy season starts in November and ends in April, while the dry season lasts from May until October). Rainfall increased more significantly in the rainy season than in the dry season, as indicated by the gradient of the higher in the former than the latter.

The monsoonal pattern is observable from the amount of rainfall and the number of rainy days per month (Figure 4). From November through March, the study area had many rainy days, but this number was much fewer in 


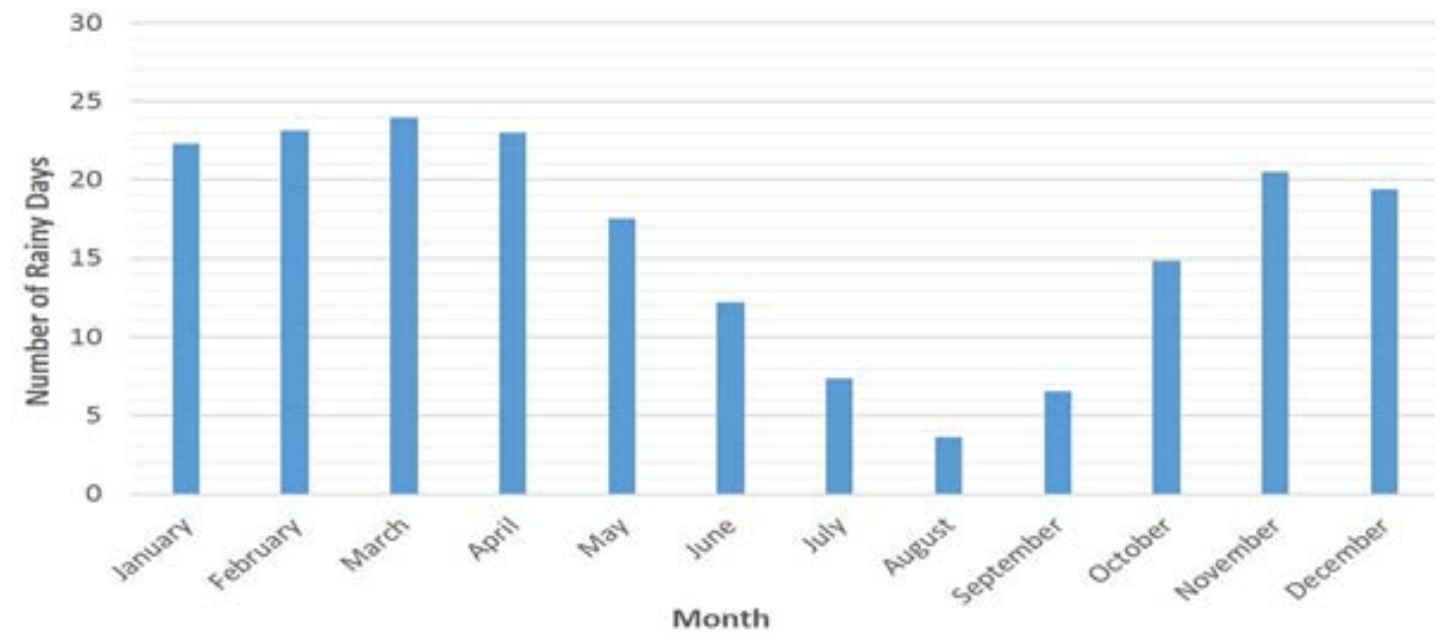

Figure 4. The number of rainy days in the Gunung Sewu karst area

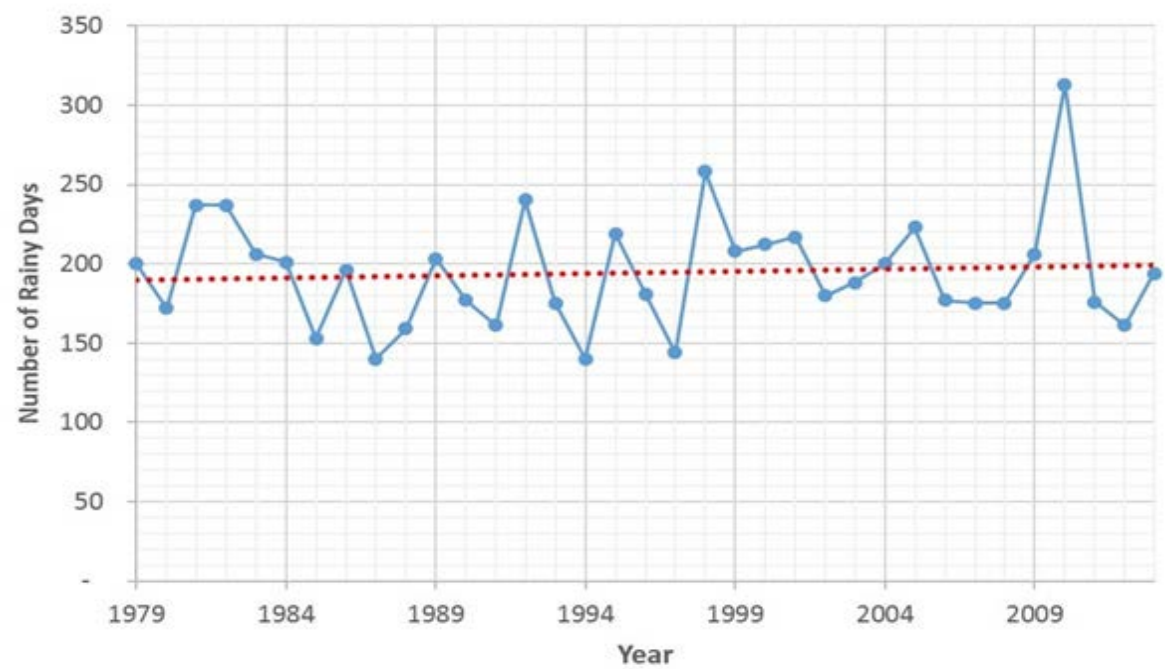

Figure 5. The trend of the number of rainy days in the Gunung Sewu karst area

May-September. Although the highest average rainfall was in February, the highest number of rainy days was in March, i.e., 24 days. August was the peak of the dry season and had the lowest number of rainy days. It also corresponds to the mean monthly rainfall, which was the least in this month. The number of rainy days is crucial in the research, especially concerning agricultural activities and flood events. Rain lasting for many days is most likely to sustain plants' lives that depend on soil moisture, such as food crops and horticulture. However, too many consecutive days of rain can oversaturate the soil and lead to landslides and floods. Gunung Sewu karst area had 193 rainy days per year. The most extended wet condition occurred in 2019, with 313 rainy days/year, while the shortest one was in 1987 and 1984, with 140 rainy days/year. In detail, the rainy season had, on average, 132 rainy days, while throughout the dry season, rains still occurred during 61 days.

Figure 5 shows an increasing trend in the number of rainy days in the Gunung Sewu karst area. The gently sloping trendline indicates no significant change for 35 years (an increase by 


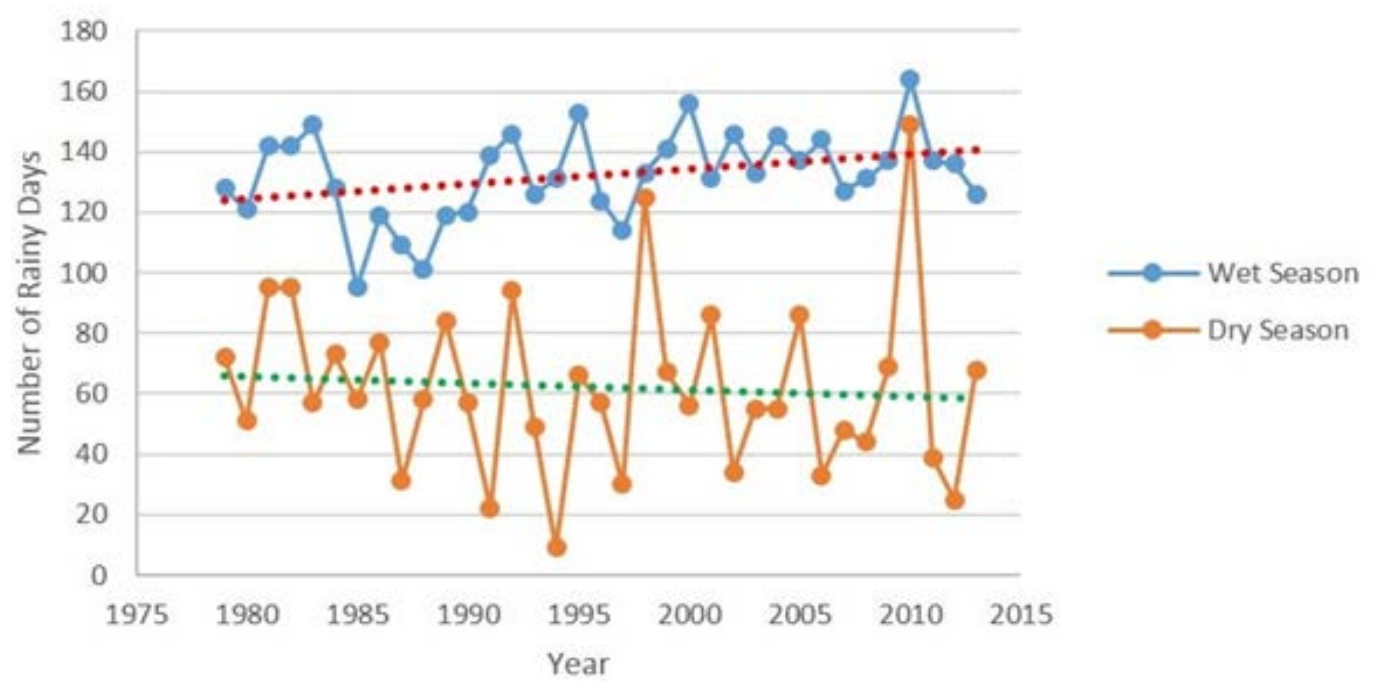

Figure 6. The trend of the number of rainy days during the rainy and dry seasons in the Gunung Sewu karst area

merely \pm 10 rainy days in this period). However, after a further study of every season, it turned out that the number of rainy days increased only during the rainy season but tended to decrease in the dry season (Figure 6). The rate of increase was \pm 20 rainy days per 35 years in the former, while in the latter, it was \pm ten rainy days per 35 years.

The Gunung Sewu karst area showed a steep increasing trend of rainfall but a less significant elevation in the number of rainy days (as evident from the gently sloping trendline). This condition led to an increase in the daily rainfall intensity (Figure 7). High rain in the area has been reported to cause floods, such as the 2017 flood that coincided with cyclone cempaka (Cahyadi, \& Mardiatno, 2019; Haryono et al., 2020; Samodra et al., 2020) and the 2019 flood due to cyclone savannah-induced rainfall (Riyanto et al., 2020). In Gunung Sewu, some landforms are prone to this disaster, namely areas surrounding the ponor where the allogenic river enters the underground river system, springs or resurgences that are controlled by large conduit flows, and karst windows and closed basins (doline) that have poor drainage because they are covered by sediments or have small-size sinkholes (Cahyadi \& Mardiatno, 2019).
Rainfall variability in the Gunung Sewu karst areais inseparable from the effect of ENSO. Figure 8 depicts the annual rainfall in Indonesia (blue line) and its relation to El Niño. From 1979 to 2013, there were eleven El Niño years, including two very strong events in 1982/83 and 1997/98. In the other nine El Niño events, rains were below the mean annual rainfall in the Gunung Sewu karst area (red line). In other words, El Niño strongly influenced the rainfall in the Gunung Sewu karst area, which is consistent with Boer et al. (2014), who has found a close link between 41 droughts in southern Indonesia (Java, Bali, Nusa Tenggara, South Sulawesi islands) from 1844 until 2009 due to El Niño. El Niño also affects Indonesia's agricultural sector; for example, in 1997/98, El Niño caused damages amounting to USD 2.75 billion and a total economic loss of USD 9 billion nationwide (Bappenas, 1999; Kirono \& Tapper, 1999).

Low rainfall as an impact of El Niño will have a devastating effect on regions where most of the populations work in the crop and agricultural livestock sectors (Ayanlade, Radeny, Morton, \& Muchaba 2018) like the Gunung Sewu karst area (Cahyadi et al., 2012; Cahyadi, 2014b). This area is mainly used for dry crop cultivations and rainfed rice farming 


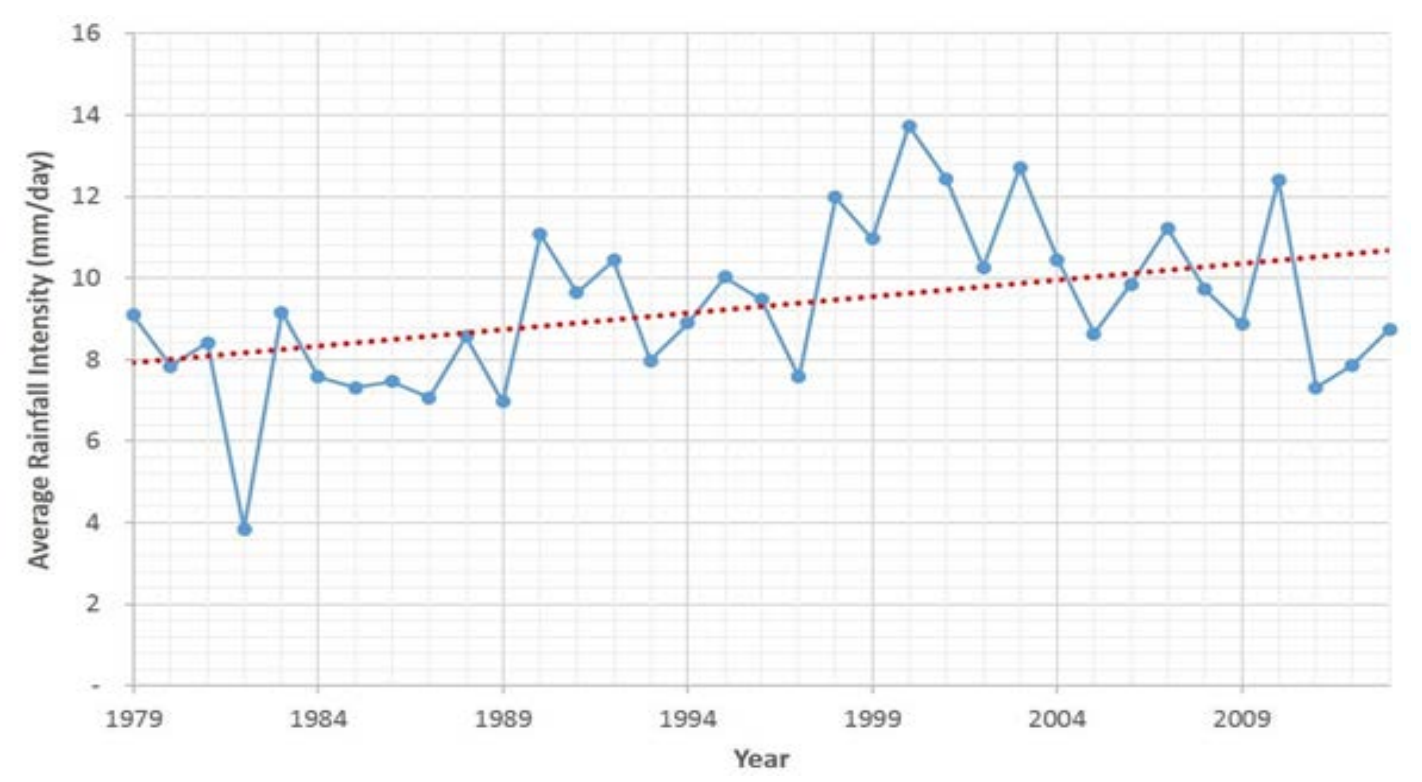

Figure 7. The Trend of daily rainfall intensity in Gunung Sewu karst area

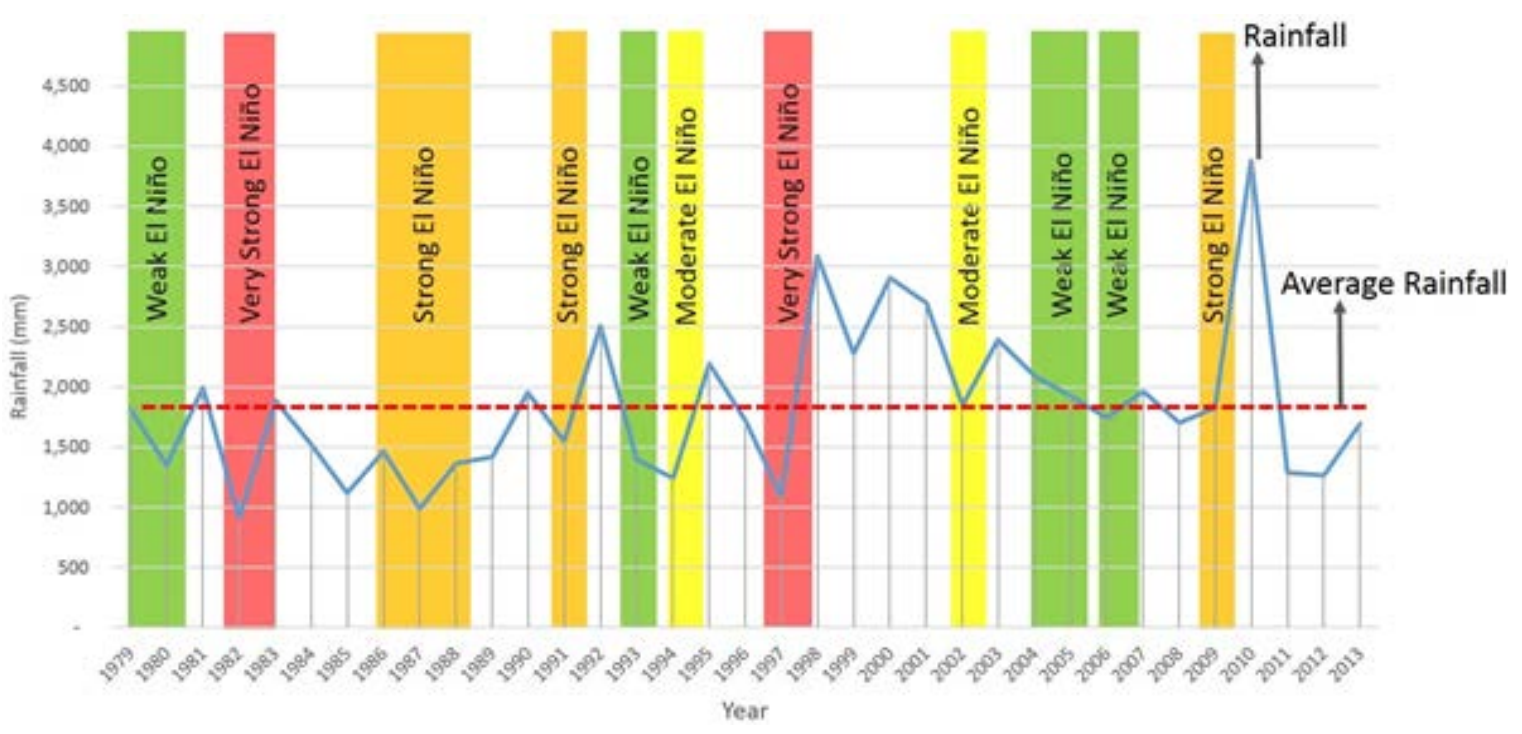

Figure 8. Rainfall data of the Gunung Sewu karst area from 1979 until 2013 with the weak, moderate, strong, and very strong El Niño years as the reference

dependent on rainwater (Naylor et al., 2007; Lestariningsih, Cahyadi, Rahmat, \& Zein, 2013). Also, very low rainfall is most likely to induce secondary disasters, namely droughts, decreased agricultural production, and food shortages (Cahyadi et al., 2013; Abaje, Sawa, \& Ati, 2014).

La Niña also shapes the rainfall variability in the Gunung Sewu karst area. Figure 9 shows the relationship between annual rainfall (red line) and La Niña events in Indonesia. From 1979 through 2013, La Niña happened seven times or fewer than El Niño. Figure 9 shows that during strong La Niña, the rainfall increased considerably compared to the average rainfall (yellow line). However, unlike El Niño, which has a strong influence, the weak and moderate La Niña years do not appear to be 


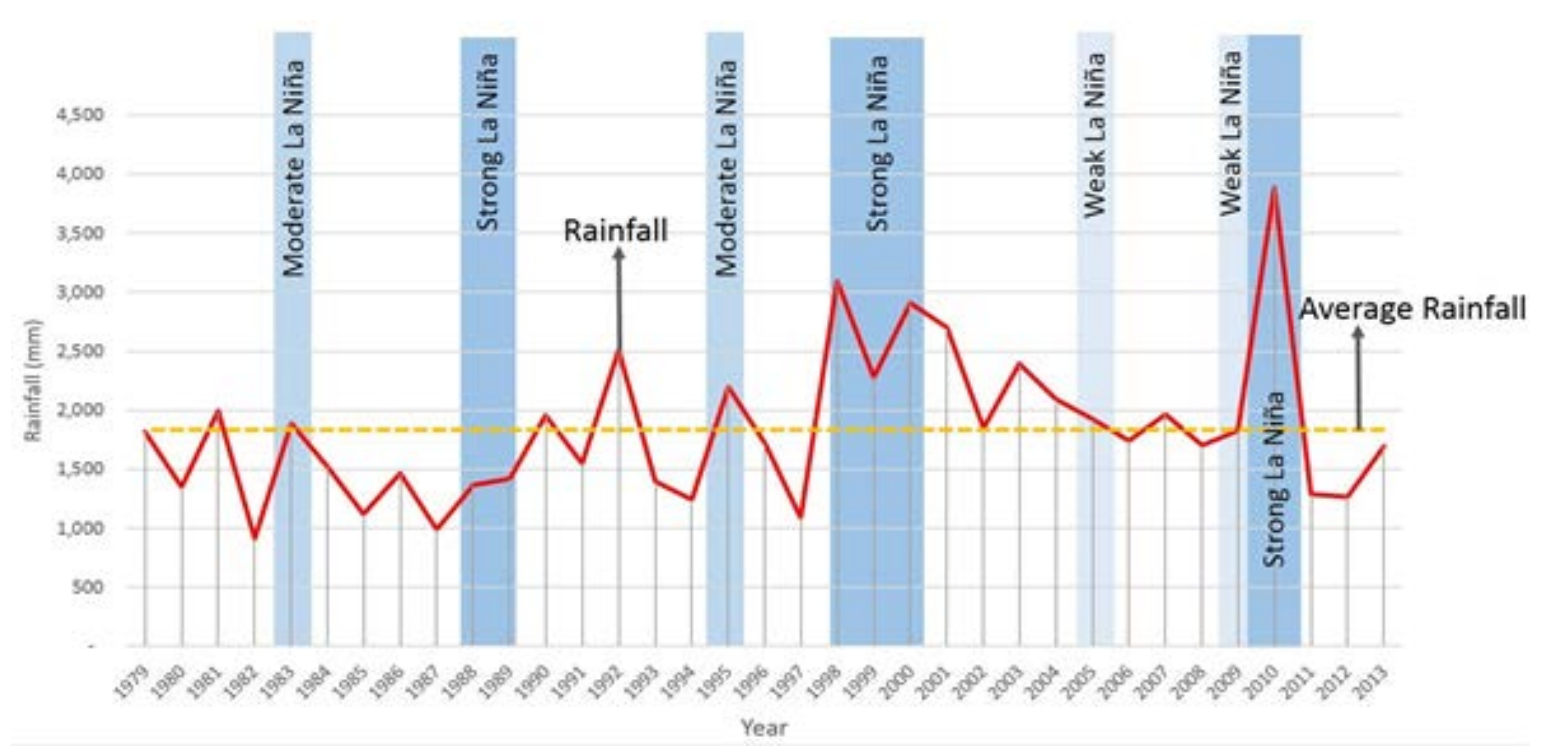

Figure 9. Rainfall data of the Gunung Sewu from 1979 until 2013 with the weak, moderate, and strong La Niña years as a reference

Table 2. Rainfall with different return periods in the Gunung Sewu karst area

\begin{tabular}{ccc}
\hline Probabilities $\mathbf{( \% )}$ & Return Periods (Year) & Rainfall (mm/day) \\
\hline 100 & 1 & 33 \\
20 & 5 & 103 \\
10 & 10 & 118 \\
5 & 20 & 130 \\
4 & 25 & 134 \\
2 & 50 & 144 \\
1 & 100 & 153 \\
0.5 & 200 & 161 \\
\hline
\end{tabular}

strong enough to affect the study area's annual rainfall. As evidence, the annual rainfall during these events was still below the mean yearly rainfall line. Hamada et al. (2002) and Hidayat and Ando (2014) also confirmed that El Niño is more likely to affect Indonesia's rainfall variability.

As presented in detail in Table 2, the highest rainfall in 35 years of recording in the Gunung Sewu karst area was $161 \mathrm{~mm} /$ day, with a return period of 200 years. The return period for 50 $\mathrm{mm} /$ day rainfall was five years, meaning that extreme rainfall events of this magnitude can occur every five years. Consequently, extreme events pose high hydrometeorological hazards in the area.

\section{CONCLUSION}

There is generally an increase in the mean annual rainfall trend, the number of rainy days, and daily rainfall intensity based on the analysis of rainfall data in the Gunung Sewu karst areafrom 1979 until 2013. In more detail, the number of rainy days in the rainy season tends to increase, while that in the dry season is decreasing. It creates a challenge to the area because the possibility of drought in the dry season will be higher. The yearly rainfall is always below the annual average during the $\mathrm{El}$ Niño events, indicating a strong influence of $\mathrm{El}$ Niño on the rain. On the contrary, La Niña has less effect, which is apparent from the absence 
of high rainfall following this climatological event.

Based on the analysis results, there are less rainfall and fewer rainy days in the dry season, but each rainy event occurs in higher intensity. In this state, drought and flood prevention should be the primary concern of future improvements of relevant disaster management infrastructure. Considering that rainy conditions, particularly in dry seasons, will be increasingly unreliable in the future, providing infrastructure for clean water extraction from underground rivers that caters to all residents of the Gunung Sewu karst areais, in this case, is a suggested option.

The analysis results show that for 35 years (1979-2014), there has been an increase in the mean annual rainfall of $650 \mathrm{~mm}$. If this amount is properly distributed temporally, it will cause more water resources reserves in the karst area. However, this study's results also indicate that there is a trend of increasing daily rainfall intensity. This condition also means that the possibility of extreme rainfall is also getting higher. This means that the increase in the average annual rainfall that occurs does mean more water resources and the possibility of extreme rainfalls and floods that can occur more frequently.

In the future, to complement this research, it is necessary to conduct further studies related to drought susceptibilities, climate change predictions, and analyses of extreme rain events. Studies surrounding their applications, e.g., flood and drought impact analysis and food security, are also essential. They can at least contribute to long-term environmental management and disaster management.

Although satellite data meet the requirements of rainfall variability analysis, field-recorded details remain necessary. Weather satellite data are not without limitations in that information with small to medium resolution is not sufficient for large-scale analysis. Field data available in long time series will facilitate and create a better analysis. Besides, the vast area of Gunung Sewu suggests that there need to be more rain gauge stations. For an even spatial distribution, at least one station should be added to each district, particularly at a location selected based on the sea's distance to provide distinct variations between rainfall conditions along the coast and far inland.

\section{ACKNOWLEDGEMENT}

This research is a part of the first Author's dissertation in the Geography Study Program, Faculty of Geography, Universitas Gadjah Mada. It received funding assistance from the Faculty of Geography, Universitas Gadjah Mada through the 2020 Independent Research Grant Scheme for the Faculty Lecturers (Hibah Penelitian Mandiri Dosen Fakultas Geografi Universitas Gadjah Mada) under the Decree of the Faculty Dean No. 1291/UN1/FGE/KPT/ SETD/2020.

\section{REFERENCES}

Abaje, I., Sawa, B., Ati, O. (2014). Climate variability and change, impacts and adaptation strategies in Dutsin-Ma Local government area of Katsina State, Nigeria. Journal of Geography and Geology, 6(2), 103-112.

Aldrian, E. (2001). Pembagian iklim Indonesia berdasarkan pola curah hujan dengan metoda "double correlation." Jurnal Sains \& Teknologi Modifikasi Cuaca, 2(1), 11-18. doi://10.29122/jstmc.v2i1.2142.

Aldrian, E., Gates, D., L., \& Widodo, F. H. (2007). Seasonal variability of Indonesian rainfall in ECHAM4 simulations and in the reanalyses: The role of ENSO. Theoretical and Applied Climatology, 87(1-4), 41-59. doi://10.1007/ s00704-006-0218-8.

Asnani, G. C. (1993). Tropical meteorology. STD Computers.

Athoillah, I., Sibarani, M., R., Doloksaribu, E. D.(2017). Analisis spasial el nino kuat tahun 2015 dan la nina lemah tahun 2016 (Pengaruhnya terhadap kelembapan, angin dan curah hujan di Indonesia). Jurnal Sains \& Teknologi Modifikasi Cuaca, 18(1), 33-41. doi://10.29122/jstmc.v18i1.2140.

Ayanlade, A., Radeny, M., Morton, J. F., \& Muchaba, T. (2018). Rainfall variability and drought 
characteristics in two agro-climatic zones: An assessment of climate change challenges in Africa. Science of the Total Environment, 630(February), 728-737. doi://10.1016/j. scitotenv.2018.02.196.

Bappenas. (1999). Planning for fire prevention and drought management project. Bappenas, Jakarta.

Boer, R., Faqih, A., \& Ariani, R. (2014). Relationship between Pacific and Indian Ocean sea surface temperature variability and rice production, harvesting area and yield in Indonesia. Proceeding of the EEPS A Conference on the Economics of Climate Change, 330-344.

Boer, R. (2003). Penyimpangan iklim di Indonesia. Proceeding of the National Seminar on Soil Science.

Brunsch, A., Stoffel, D., Ikhwan, M., Oberle, P., \& Nestmann, F. (2011). Hydrological assessment of a karst areain southern Java with respect to climate phenomena. Asian Trans-Disciplinary Karst Conference, January, 10.

Cahyadi, A., Nugraha, H., \& Nucifera, F. (2013). Pengaturan pola tanam meteorologis sebagai salah satu upaya optimalisasi produktivitas pertanian di kawasan karst Kabupaten Gunung Kidul. In H. Sudarmadji; Haryono, E.; Adji, T.A.; Widyastuti, M.; Harini, R.; Nurjani, E.; Cahyadi, A.; Nugraha (Ed.), Ekologi lingkungan kawasan karst Indonesia: menjaga asa kelestarian kawasan karst Indonesia. Deepublish. 10.31227/osf.io/k4sqe.

Cahyadi, A. \& Mardiatno, D. (2019). Mewaspadai bencana hidrometeorologis di kawasan karst. Kedaulatan Rakyat Daily Newspaper.

Cahyadi, A. (2014a). Keunikan hidrologi kawasan karst: Suatu tinjauan. In H. Cahyadi, A., Prabawa, B.A., Tivianton, T.A., Nugraha (Ed.), Ekologi lingkungan kawasan karst Indonesia: menjaga asa kelestarian kawasan karst Indonesia ( $2^{\text {nd }}$ ed., pp. 1-13). Deepublish. doi://10.31227/osf.io/awvqs.

Cahyadi, A. (2014b). Sumber daya lahan kawasan karst Gunungsewu. In H. Cahyadi, A., Prabawa, B.A., Tivianton, T.A., Nugraha (Eds.), Ekologi lingkungan kawasan Karst Indonesia: menjaga asa kelestarian kawasan karst Indonesia (2 $2^{\text {nd }}$ ed., pp. 102-113). Deepublish. doi://10.31227/osf.io/4dbr5.

Cahyadi, A., Haryono, E., Adji, T. N., Widyastuti, M., Riyanto, I. A., Nurteisa, Y. T.,
Fatchurohman, H., Reinhard, H., Agniy, R. F., Nurkholis, A., Naufal, M., \& Nurjani, E. (2019). Groundwater flooding due to tropical cyclone cempaka in Ngreneng karst window, Gunung Sewu karst area, Indonesia. E3S Web of Conferences, 125 (2019). doi://10.1051/ e3sconf/ 201912501020.

Cahyadi, A., Marfai, M. A., Rahmadana, A. D. W., \& Nucifera, F. (2012). Perencanaan penggunaan lahan di kawasan karst berbasis analisis kemampuan lahan dan pemetaan kawasan lindung sumberdaya air. Proceedings of the National Seminar on Science, Engineering and Technology, December 2018, 22-23. doi://10.31227/osf.io/6b49a.

Cahyadi, Ahmad, Nugraha, H., Wacano, D., \& Fatchurohman, H. (2012). Peran organisasi masyarakat dalam strategi adaptasi kekeringan di Dusun Turunan, Kecamatan Panggang, Kabupaten Gunung Kidul (Sebuah pembelajaran dalam adaptasi dampak perubahan iklim di masa mendatang). Prosiding Seminar Nasional Perubahan Iklim, December. doi://10.31227/osf.io/md957.

Christanto, N., Setiawan, M. A., Nurkholis, A., Sartohadi, J., \& Hadi, M. P. (2020). The use of global datasets in the SWAT model for tropical watershed with limited ground data: A case study in Serayu upper catchment. Taiwan Water Conservancy, 68(3), 18-27.

Dile, Y. T., \& Srinivasan, R. (2014). Evaluation of CFSR climate data for hydrologic prediction in data-scarce watersheds: An application in the blue nile river basin. Journal of the American Water Resources Association, 50(5), 1226-1241. doi://10.1111/jawr.12182.

Dipayana, G.A., Cahyadi, A., Mutaqin, B.W., \& Nurjani, E. (2012a). Dampak perubahan iklim terhadap nilai erosivitas di DAS OPAK berdasarkan skenario perubahan iklim HadCM3 skenario A2 dan B2. Proceedings of the Science, Engineering and Technology. doi://10.31227/osf.io/v3f7b.

Dipayana, G.A., Nurjani, E., Adji, T. (2012b). Estimasi distribusi spasial imbuhan airtanah menggunakan model water-budget dan Geographic Information System (GIS) di DAS Opak, DIY. Proceedings of the Science, Engineering and Technology, 1-7.

Fatchurohman, H., \& Cahyadi, A. (2013). Strategi 
adaptasi masyarakat terhadap bencana kekeringan di kawasan karst Kecamatan Panggang, Gunung kidul. In H. Sudarmadji, Haryono, E., Adji, T.A., Widyastuti, M., Harini, R., Nurjani, E., Cahyadi, A., Nugraha (Ed.), Ekologi lingkungan Kawasan Karst Indonesia: menjaga asa kelestarian Kawasan Karst Indonesia (pp. 1-12). Deepublish. https:// www.academia.edu/6261679/Strategi_ adaptasi_lingkungan_masyarakat_awasan_ karst.

Fuka, D. R., Walter, M. T., Macalister, C., Degaetano, A. T., Steenhuis, T. S., \& Easton, Z. M. (2014). Using the climate forecast system reanalysis as weather input data for watershed models. Hydrological Processes, 28(22), 5613-5623. doi://10.1002/hyp.10073.

Green, S. M., Dungait, J. A. J., Tu, C., Buss, H. L., Sanderson, N., Hawkes, S. J., Xing, K., Yue, F., Hussey, V. L., Peng, J., Johnes, P., Barrows, T., Hartley, I. P., Song, X., Jiang, Z., Meersmans, J., Zhang, X., Tian, J., Wu, X., ... Quine, T. A. (2019). Soil functions and ecosystem services research in the Chinese karst critical zone. Chemical Geology, 527, [119107], doi://10.1016/j.chemgeo.2019.03.018.

Gutman, G., Csiszar, I., \& Romanov, P. (2000). Using NOAA/AVHRR products to monitor El Niño impacts: Focus on Indonesia in 1997 98. Bulletin of the American Meteorological Society, 81(6), 1189-1205. doi://10.1175/15200477(2000)081<1189:UNPTME>2.3.CO;2.

Hamada, J. I., Yamanaka, M. D., Matsumoto, J., Fukao, S., Winarso, P. A., \& Sribimawati, T. (2002). Spatial and temporal variations of the rainy season over Indonesia and their link to ENSO. Journal of the Meteorological Society of Japan, 80(2), 285-310. doi://10.2151/ jmsj.80.285.

Haryono, E., Cahyadi, A., Nurrohman,, A.M., Adzan, G., Nasution, A. L., Diah, H., \& Sari Septianingrum, R. (2020). Dinamika luweng belimbing, kawasan karst Gunung Sewu pasca siklon tropis cempaka tahun 2017. Jurnal Geografi, 12(01), 39-45. doi://10.24114/ jg.v12i01.14769.

Haylock, M., \& McBride, J. (2001). Spatial coherence and predictability of Indonesian wet season rainfall. Journal of Climate, 14(18), 3882-3887. doi://10.1175/1520-
0442(2001)014<3882:SCAPOI>2.0.CO;2.

Hermawan, E. (2010). Pengelompokkan pola curah hujan yang terjadi di beberapa kawasan P. Sumatera berbasis hasil analisis teknik spektral. Jurnal Meteorologi dan Geofisika, 11(2),75-85. doi://10.31172/jmg.v11i2.67.

Hidayat, R., \& Ando, K. (2018). Variabilitas curah hujan Indonesia dan hubungannya dengan ENSO/IOD: Estimasi menggunakan data JRA-25/JCDAS. Agromet, 28(1), 1-8. doi://10.29244/j.agromet.28.1.1-8.

Juaeni, I. (2006). Analisis variabilitas curah hujan wilayah indonesia berdasarkan pengamatan tahun 1975-2004. Matematika, 9(2), 171-180.

Kang, Z., Chen, J., Yuan, D., He, S., Li, Y., Chang, Y., Deng, Y., Chen, Y., Liu, Y., Jiang, G., Wang, X., \& Zhang, Q. (2020). Promotion function of forest vegetation on the water \& carbon coupling cycle in karst critical zone: Insights from karst groundwater systems in south China. Journal of Hydrology, 590, [125246]. doi://10.1016/j.jhydrol.2020.125246.

Kirono, D. G. C., \& Tapper, N. J. (1999). Enso rainfall variability and impacts on crop production in Indonesia. Physical Geography, 20(6), 508-519. doi://10.1080/02723646.1 999.10642693.

Lestariningsih, S.P., Cahyadi, A., Rahmat, P. N., \& Zein, A. G. I. (2013). Tekanan penduduk terhadap lahan di Kawasan Karst (Studi kasus di Desa Songbanyu, Kecamatan Girisubo dan Desa Jeruk Wudel Kecamatan Rongkop, Gunung Kidul). December. doi://10.31227/ osf.io/kcj6h.

Naylor, R. L., Battisti, D. S., Vimont, D. J., Falcon, W. P., \& Burke, M. B. (2007). Assessing risks of climate variability and climate change for Indonesian rice agriculture. Proceedings of the National Academy of Sciences of the United States of America, 104(19), 7752-7757. doi://10.1073/pnas.0701825104.

Qian, J. H., Robertson, A. W., \& Moron, V. (2010). Interactions among ENSO, the monsoon, and diurnal cycle in rainfall variability over Java, Indonesia. Journal of the Atmospheric Sciences, 67(11), 3509-3524. doi://0.1175/2010JAS3348.1.

Quine, T., Guo, D., Green, S. M., Tu, C., Hartley, I., Zhang, X., Dungait, J., Wen, X., Song, Z., Liu, H., Buss, H., Barrows, T., Evershed, 
R., Johnes, P., \& Meersmans, J. (2017). Ecosystem service delivery in Karst landscapes: anthropogenic perturbation and recovery. Acta Geochimica, 36(3), 416-420. doi://10.1007/s11631-017-0180-4.

Ramage, C. (1971). Monsoon meteorology. In International Geophysics Series $\left(15^{\text {th }}\right.$ ed., pp. 365-370). Retrieved from Academic Press. https://www.sciencedirect.com/ bookseries/internationalgeophysics/ $\mathrm{vol} / 15 / \mathrm{suppl} / \mathrm{C}$

Ramage, C. . (1968). Role of a tropical marine continent in the atmospheric circulation. Monthly Weather Review, 96(6), 365-370.

Riyanto, I. A., Cahyadi, A., Ramadhan, F., Naufal, M., Widyastuti, M., \& Adji, T. N. (2020). Dampak siklon tropis savannah pada karst Window Kalinongko, Karst Gunung Sewu, Kabupaten Gunung Kidul, Indonesia. Jurnal Geografi, 17(1), 7-14. doi://10.15294/ jg.v17i1.21419.
Samodra, G., Ngadisih, N., Malawani, M. N., Mardiatno, D., Cahyadi, A., \& Nugroho, F. S. (2020). Frequency-magnitude of landslides affected by the 27-29 November 2017 tropical cyclone cempaka in Pacitan, East Java. Journal of Mountain Science, 17(4), 773786. doi://10.1007/s11629-019-5734-y.

Stefanidis, S., \& Stathis, D. (2018). Spatial and temporal rainfall variability over the mountainous central Pindus (Greece). Climate, 6(3)1-15. doi://10.3390/cli6030075.

Suprayogi, S., Cahyadi, A., Tivianton, T.A., Riyadi, S., Fajri, A.A., Sasongko, T.R. and Arida, V. (2014). Analisis dampak perubahan iklim terhadap curah hujan tahunan menggunakan skenario iklim HadCM3 dengan skenario emisi A2 dan B2 analisis di DAS Progo Hulu. Pekan Imiah Tahunan Ikatan Geograf Indonesia. https://10.0.68.197/OSF.IO/AY7S3. 